\title{
СООБЩЕНИЯ. ЗАМЕТКИ
}

DOI 10.22455/2541-8297-2017-3-201-214

УДК 821.161 .1

ББК 83.3 (2 Рoc=Pyc)

\section{Поэт Александр Слепецкой. Литературная мистификация в журнале «Муза» (1796) \\ К.Ю. Лаппо-Данилевский}

\begin{abstract}
Аннотация: Статья посвящена раскрытию псевдонима, который более 220 лет скрывал имя поэта Александра Михайловича Бакунина (1768-1854). Так как небольшое предисловие к двум его стихотворениям написал литератор и архитектор Николай Александрович Львов (1753-1803), то их правомерно рассматривать в контексте других публикаций участников львовско-державинского кружка в журнале «Муза». В статье предложен ряд гипотез и уточнений относительно криптонимов, использовавшихся как в «Музе», так и в изданиях Н.М. Карамзина 1790-х годов.
\end{abstract}

Ключевые слова: атрибуция, псевдонимы, Н.А. Львов, А.М. Бакунин, львовско-державинский кружок, журнал «Муза».

Информация об авторе: Константин Юрьевич Лаппо-Данилевский, д.ф.н., Институт русской литературы (Пушкинский Дом) РАН, Санкт-Петербург, Россия. E-mail: litfact@gmail.com

Иван Иванович Мартынов - один из тех немногих русских писателей, кто начал вхождение в литературу в 1790-е годы и оставил об этом воспоминания. Из них узнаем, что, не будучи лично знаком с издателями «Санкт-Петербургского Меркурия» И.А. Крыловым и А.И. Клушиным, он в 1793 г. предложил для публикации в нем свои стихотворения «К бардам» и «Взор на протекшие лета» и был крайне обрадован их скорым напечатанием в мартовском номере журнала. Издатели, впрочем, сочли возможным снабдить некоторые строки оценочными примечаниями, что дебютанта нисколько не обидело (сам он через несколько лет стал практиковать то же самое по отношению к начинающим литераторам), и Мартынов продолжил печататься в «Санкт-Петербургском Меркурии», сблизившись с его издателями. Когда в том же году по внешним, не до конца ясным причинам, журнал должен

* Статья написана в рамках работы по проекту «Русская анакреонтическая ода XVIII - первой четверти XIX века», поддержанного грантом РГНФ (№ 16-04-00280). 
был прекратить существование, а Крылов и Клушин покинули столицу, именно Мартынову было поручено отредактировать два последних номера.

Этот опыт, несомненно, сыграл определенную роль, когда вскоре Мартынов решил издавать свой журнал «Муза». Женившись к тому времени, он был крайне заинтересован в литературном заработке, и журнал оправдал его расчеты. Остается лишь пожалеть, что его мемуарный рассказ об этом предприятии более чем краток:

«Вступив в новый род жизни, умноживший мои нужды, я на другой же год (1796) приступил к изданию журнала, под названием: „Муза“. В журнал мой сообщали сочинения свои в прозе и стихах: Державин, Сперанский, Львовы, Николай Александрович и Федор Петрович, Словцов и другие. Журнал пошел недурно, судя по тогдашнему времени. И так моя служба, учительство и издание журнала доставили нам изрядные средства к содержанию» ${ }^{1}$.

Работа над «Записками» велась Мартыновым более чем через тридцать лет после описываемых событий, поэтому, как кажется, мемуарист, не вдаваясь в подробности, перечислил имена тех, с кем в наибольшей степени имел дело лично. То, что имя Державина было помещено на первом месте, не нуждается в комментариях - тем самым отдавалось должное его таланту и его значению в литературной жизни конца XVIII столетия ${ }^{2}$. М.М. Сперанский и П.А. Словцов ${ }^{3}$ учились вместе с Мартыновым в Александро-Невской духовной семинарии, дружеские отношения с ними сохранились на многие годы. Н.И. Анненский, еще один бывший

${ }^{1}$ Мартынов И.И. Записки // Памятники новой русской истории. Сборник исторических статей и материалов, изд. В. Кашпиревым. СПб., 1872. Т. 2. С. 95 (2-ая паг). Чуть ниже Мартынов отмечает, что «Муза» стала известна при дворе и что вел. княжна Александра Павловна сообщила ему два своих перевода, которые он и напечатал в журнале.

2 О благоволении Державина к журналу свидетельствует то, что уже в первой части его имя значится среди особ, подписавшихся на издание; из других активных вкладчиков предприятия здесь значатся Д.И. Хвостов, И.И. Дмитриев, М.М. Сперанский и Н.И. Анненский (Муза. 1796. Ч. І. Март. С. 261, 263). В аналогичном разделе второй части указаны Н.А. Львов и П.А. Слопцов (Словцов) (Там же. 1796. Ч. ІІ. Июнь. С. 265), а в третьей Е.А. Колычев и А.Т. Болотов (Там же. 1796. Ч. ІІІ. Сент. С. 270). Последний из упомянутых писателей, впрочем, в журнале не публиковался, но с интересом его читал и оставил о нем сочувственный отзыв, хотя и сетовал на его высокую цену (Болотов А.T. Памятник протекших времен, или Краткие исторические записки о бывших происшествиях и носившихся в народе слухах. М., 1875. Ч. 1. С. 104).

${ }^{3}$ Чуть выше Мартынов указал, какие именно стихотворения в «Музе» принадлежат П.А. Словцову: «К Сибири» и «Материя» (Мартынов И.И. Записки. С. 77). 
соученик по семинарии, активно печатавшийся в «Музе», в этом абзаце не упомянут, также как и Г.И. Мансветов, «первый» ученик Мартынова «в поэзии, риторике и в греческом языке» ${ }^{4}$.

Знакомство Мартынова с Н.А. Львовым состоялось, видимо, около 1793 года, когда тот начинал свою работу над переводами стихов Анакреонта и античных подражаний ему, составивших сборник «Стихотворение Анакреона Тийского» (1794). Евгений Булгарис, не знавший в достаточной степени русского языка, по всей видимости, рекомендовал Мартынова Львову, когда тому потребовался подстрочник переводимых греческих стихов ${ }^{5}$. Мартынов, судя по всему, именно через Н.А. Львова привлек к участию в «Музе» Г.Р. Державина, а также Ф.П. Львова (двоюродного брата Н.А. Львова), которые в «Санкт-Петербургском Меркурии» Клушина и Крылова своих произведений не публиковали. Исследователи не раз справедливо отмечали карамзинистскую ориентацию «Музы» ${ }^{6}$, а при привлечении в журнал московских литераторов, сотрудничавших в изданиях Карамзина, державинское окружение могло оказать Мартынову бесценную помощь.

Упоминание Мартыновым имен лишь пяти литераторов и краткость сведений об их участии в «Музе» вызывают и сожаление, и удивление. А.Н. Неустроев в «Историческом разыскании о русских повременных изданиях и сборниках» из литераторов, поименованных Мартыновым в качестве авторов журнала, назвал лишь Державина и Сперанского, а в росписи содержания привел библиографические сведения об их публикациях в «Музе». То же самое он сделал в отношении выдающихся писателей, Мартыновым не названных, таких, как И.И. Дмитриев, Н.М. Карамзин, В.А. Жуковский, указав их псевдонимы ${ }^{7}$. В качестве других вкладчиков журнала им перечислены: Н.И. Анненский, А.И. Бухарский, А.П. Елоховский, Е.А. Колычев, А.И. Леванда, П.Ю. Львов, А. Слепецкий, Д.И. Хвостов, А.А. Шаховской и другие ${ }^{8}$.

${ }^{4}$ Они упоминаются в «Записках» Мартынова по другому поводу: Там же. C. $77,87$.

${ }^{5}$ Гаврилов А.К. Евгений Булгарис // Словарь русских писателей XVIII века. Л., 1988. Вып. 1: А-И. С. 134.

6 Залдкин А.Н. Иван Иванович Мартынов (1771-1833), деятель просвещения в начале XIX века. Тифлис, 1902. С. 16.

${ }^{7}$ Среди авторов журнала А.Н. Неустроев вслед за Н.С. Тихонравовым называл также Г.П. Каменева, якобы скрывшегося под псевдонимом «I-* VII-*», что отнюдь не бесспорно (Петровский Н.М. Библиографические заметки о русских журналах XVIII века // Журнал Министерства народного просвещения. 1898. Ч. 315. Янв. С. 102-103).

${ }^{8}$ Неустроев А.Н. Историческое разыскание о русских повременных изданиях и сборниках за 1703-1802 гг. СПб., 1874. С. 797. См. также далее роспись содержания журнала. Тот же перечень авторов находим при характери- 
Впервые идентифицировать публикации Н.А. Львова в «Музе» удалось 3.В. Артамоновой, которая обратила внимание на выписку из этого журнала в рукописном томе сочинений поэта, хранящемся в архиве Г.Р. Державина в Публичной библиотеке 9 . Речь идет о прозаическом обращении «К Доралисе» и последующих «Стихах на розу, сорванную зимою 1796 года и посланную в рисунке к Доралисе», подписанных в «Музе» латинской литерой «N» ${ }^{10}$. Сделанное наблюдение позволило атрибутировать Н.А. Львову еще одно стихотворение и верно раскрыть имя его адресата - это «Отрывок из письма к А.М. Б[акунину], который к сочинителю прислал из деревни стихи на зависть, скуку, на воображение, на праздность», подписанный той же литерой ${ }^{11}$. «Отрывок» написан вольными ямбами и по стилю близок к другим посланиям Н.А. Львова, в то время бытовавшим лишь в рукописном виде.

В ходе работы над «Сводным каталогом книг гражданской печати XVIII века» было установлено, что Мартынов напечатал в первой части «Музы» еще одно, крупное произведение Львова без указания имени автора, а именно: поэму «Зима» ${ }^{12}$, которая вышла в свет в 1791 г. в Санкт-Петербурге отдельным анонимным изданием столь малого тиража, что была публике неизвестна ${ }^{13}$. Мартынов снабдил текст поэмы следующим примечанием: «Кого благодарить за эту пиесу? я надеюсь, что всяк будет повторять со мною сей вопрос, прочитав оную» ${ }^{14}$. Возможно, это удивление было деланным, но полностью исключить и то, что издателю «Музы» не было точно известно имя автора, мы не можем.

Обратимся наконец к непосредственному сюжету данной статьи. В третьей части «Музы», в номере за август, с заголовком «К издателю» были опубликованы следующие строки:

«Я украл* две пиесы у старого приятеля, одного молодого стихотворца, и с именем его. Этот молодец пишет хорошие стихи и прячет. Первая по легкости своего слога по общему признанию ремесленных людей Парнасского исповедания стоит быть известною. Вторая будет при-

стике «Музы» в кн.: Сводный каталог русской книги гражданской печати XVIII века: 1725-1800. М., 1966. T. IV: периодические и продолжающиеся издания. С. 151-152.

${ }^{9}$ РНБ. Ф. 247 (Г.Р. Державин). Т. 37. Л. 70 об.-71. См.: Артамонова 3. Неизданные стихи Н.А. Львова // Литературное наследство. 1933. № 9/10. С. 270.

${ }^{10}$ Муза. 1796. Ч. ІІ. Май. С. 131-132, 132-133.

11 Там же. 1796. Ч. ІІ. Июнь. С. 192-195.

12 Там же. 1796. Ч. І. Февр. С. 129-138; Март. С. 175-181. В журнальной публикации опущено посвящение и стихи 251-259.

${ }^{13}$ Об авторстве Н.А. Львова сообщил еще митрополит Евгений Болховитинов в «Словаре русских светских писателей, соотечественников и чужестранцев, писавших в России» (М., 1845. Т. 2. С. 38).

${ }^{14}$ Муза. 1796. Ч. І. Февр. С. 129. 
ятна, по сердцу многих, которые связаны дружбою с теми самыми людьми, кои писали и к кому писали».

Вместо подписи под этим кратким обращением стояла звездочка, а к слову «украл» Мартыновым внизу страницы было сделано примечание: «А издатель за то покорнейше благодарит» ${ }^{15}$.

Далее было помещено стихотворение «К Лизетте. Встреча», подписанное следующим образом: «Александр Слепецкой». А чуть ниже указывалось, что еще одно стихотворение того же автора планируется вскоре напечатать: «другая пиеса помещена будет в следующем месяце».

Приведу текст первого из стихотворений, о которых идет речь:

\section{К ЛИЗЕТТЕ}

\section{Встреча}

Звезды на небе чуть блещут,

Ждут веселых дней царя;

Сквозь подвижный лист трепещут

Радость утра и заря.

Встань, о Лиза! голосистой

Уже петел возгласил,

И Зефир росой душистой

Кудри Лизы окропил.

Уже небо голубеет,

Аромат цветы лиют,

На ключе туман белеет,

Птички гимн любви поют.

День прекрасный — возвратися!

[Освети лицо полей!]

Лиза милая! проснися,

Из цветов вязанку свей,

Встретим солнце на восходе,

Бог сей примет с высоты,

В жертву чистую Природе,

Нашу радость и цветы.

\section{К солниу обращаясь}

Начало жизни, Царь Природы,

Отец прекрасныя Весны!

Ты освещаешь все народы,

Одушевляешь все страны.

Едва ли смертной заблуждает,

Того равняя Божеству,

Кто все живит, растит, питает,

Дает устав и естеству!

${ }^{15}$ Муза. 1796. Ч. ІІІ. Авг. С. 180. 
Но ежели для славы вечной

Мир целый - невместимый Храм,

То образ свой в тебе, конечно,

Бог начертал в утеху нам.

Прими от нас цветы простые,

Мы сыплем их перед тобой,

Пошли не горы нам златые -

Любовь, здоровье и покой. ${ }^{16}$

Перелистывая не так давно в очередной раз «Музу», я с бо́льшим, видимо, чем ранее, вниманием прочел этот текст и понял, что передо мной стихотворение Александра Михайловича Бакунина (1768-1854), участника львовско-державинского кружка на позднем этапе его существования ${ }^{17}$.

В архиве Бакуниных в Пушкинском Доме хранятся многочисленные редакции стихотворения «К Лизетте. Встреча», причем во всех них содержится четырнадцатая строка, рифмующаяся с шестнадцатой; в «Музе» она почему-то заменена отточием. В вышеприведенном тексте эта строка восстановлена мною по рукописям (заключена в прямые скобки [ ]). Одна из редакций этого стихотворения, озаглавленная «Утро», наиболее репрезентативная и более поздняя по отношению к напечатанной в «Музе», была мною опубликована в 1994 г. ${ }^{18}$ С тоит отметить и то, что в одной из поздних версий стихотворения поэт обращался уже не к Лизетте, а к Вареньке. К тому времени (а именно с 1810 года) он уже был женат на Варваре Александровне Муравьевой. Заслуживает внимания то, что все редакции этого стихотворения двусоставны: четырехстопный хорей сменяется четырехстопным ямбом в обращении к солнцу. Избранный псевдоним объясняется просто: Бакунин крайне плохо видел, в письмах он неоднократно жаловался на «слепоту», одна из его поздних поэм озаглавлена по первой строке: «О слепота, порок большой...»"

Приведу и второе стихотворение, появившееся в следующем, сентябрьском номере «Музы» с указанием «другая пиеса Александра Слепецкого»:

${ }^{16}$ Муза. 1796. Ч. ІІІ. Авг. С. 180-181.

${ }^{17}$ Наиболее подробную на данный момент биографию А.М. Бакунина см. в кн.: Сысоев В.И. Бакунины. Тверь, 2002. С. 57-137 (глава «Александр Михайлович Бакунин - создатель „прямухинской“ гармонии»).

${ }^{18}$ Из литературного наследия А.М. Бакунина / Публ. К.Ю. Лаппо-Данилевского // Литературный архив. Материалы по истории русской литературы и общественной мысли. СПб., 1994. С. 104-105.

${ }^{19}$ Впервые опубликована: Бакунин А.M. Собрание стихотворений / Изд. подгот. М.В. Строганов. Тверь, 2001. С. 134-144. Ср. также начальную строку «Слепой очима, духом зрячий» «Эпистолы к А.М. Бакунину из Павловска, июня 14, 1797» Н.А. Львова. 


\section{СОЛОВЕЙ}

для Темиры, она же и Танюша

Померкли неба ясны своды, И сумрак тенью легких крыл

Великолепие Природы

Завесой тонкою покрыл, Зефирова стыдяся взора - .

Так прячется младая Флора, Когда резвиться хочет с ним. И голос соловьиный, чистой Разлился по струе сребристой, Прохладным ветерком носим.

Прелеста на брегу сидела, Ей мнилось, что поет Любовь; Вставала, прочь идти хотела, На мураве садилась вновь; Тревожна, млела, восхищалась, Невольно грудь ея вздымалась, Катились слезы из очей. Невинно сердце трепетало, Чего-то ей не доставало, Твердил счастливый соловей.

В глубокой думе не слыхала, Что сосны стонут на корнях, Что молния вдали блистала, Что месяц скрылся в облаках:

Но вдруг с чела венок душистый Сорвал вихрь, - дуб ветвистый, Разбитый вдребезги, упал.

Небесны потряслися своды, И Похвист к ужасу Природы, Боряся с лесом, завывал.

Прелеста всюду озиралась, И ужас грудь ее теснил, Остаться и уйти боялась, Холодный пот ее покрыл. Но в виде юноши младого Лель, с терема сошед святого, В уста ее поцеловал, И поцелуй его священный, Блеснув, как огнь, в ночи возженный, Прелесты ужас разогнал. 
Утихло все, гроза минула,

Опять ручей блеснул меж гор;

Опять в ручей Луна взглянула,

Зефир поколебал сыр бор,

Цветы дохнули ароматом,

И с громким соловья раскатом

С востока радость рассвела.

Заря, румянцем обливаясь,

Туманом легким закрываясь,

Улыбкой тьму разогнала ${ }^{20}$.

В отличие от первого стихотворения, рукописи «Соловья» среди бумаг А.М. Бакунина не сохранились ${ }^{21}$, что, конечно же, никоим образом не дает оснований для сомнения в его авторстве. Выделенная курсивом строка «Чего-то ей не доставало», как и тематика стихотворения (любовное томление девы, желанность неизведанных ласк), явственно указывают на претекст - это «Идиллия. Вечер 1780 года ноября 8» Н.А. Львова, впервые анонимно опубликованная в 1783 г. в «Собеседнике любителей российского слова» ${ }^{22}$. Стоит процитировать и пассаж, к которому отсылает Бакунин:

Елмира так же ощущала:

Но что? того сама не знала.

Когда она ложилась спать,

Тогда в ней сердце трепетало,

Покойно не могла лежать,

Чего-то ей недоставало... 23

Обращает на себя внимание шестой стих третьей строфы («Сорвал вихрь, - дуб ветвистый»), крайне затрудненный и к тому же трехстопный, в отличие от прочих четырехстопных ямбических стихов; это наводит на мысль о том, что и эта строка могла быть по каким-то причинам испорчена переписчиками текста или же наборщиком «Музы».

В связи с изложенным выше, думаю, вряд ли можно усомниться, что именно Н.А. Львов был автором обращения «К изда-

${ }^{20}$ Муза. 1796. Ч. III. Сент. С. 196-198.

21 В наиболее полном на данный момент собрании стихов поэта его поэтому нет: Бакунин А.М. Собрание стихотворений / Изд. подгот. М.В. Строганов. Тверь, 2001.

${ }^{22}$ Собеседник любителей российского слова. 1783. Ч. 1. С. 28-32. Как известно, дата в названии этого гривуазного стихотворения отсылает к дню тайного венчания Н.А. Львова. Об этом событии см. следующую итоговую работу (здесь же литература вопроса): Дзюбанов С.Д. «Верует в Резон, как во Единого Бога» (подлинная история тайной женитьбы Н.А. Львова) // Г.Р. Державин и его время. СПб., 2008. Вып. 4. С. 5-56.

${ }^{23}$ Собеседник любителей российского слова. 1783. Ч. 1. С. 30. 
телю» в третьей части «Музы», предваряющего стихи А.М. Бакунина. Именно он, как никто другой, имел право именовать «одного молодого стихотворца» своим «старым приятелем»: вскоре после возвращения в 1790 г. А.М. Бакунина из Италии между ними завязываются близкие дружеские отношения, а их литературные интересы играют при этом не последнюю роль.

Весьма существенно упоминание в цитированных выше строках обращения «К издателю» неких «ремесленных людей Парнасского исповедания», одобривших первое стихотворение: тут, конечно же, имелись в виду участники львовско-державинского кружка, творческие узы которых были «подкреплены» узами родственными. Напомню, что матерью сестер Дьяковых, на которых были женаты Н.А. Львов, Капнист и Державин, была Евдокия Петровна Дьякова, урожд. княжна Мышецкая, родная сестра княжны Любови Петровны Мышецкой, матери А.М. Бакунина. Княжны Евдокия Петровна и Любовь Петровна Мышецкие в то же время приходились двоюродными тетками Н.А. Львову, а его жена, урожденная Мария Алексеевна Дьякова, соответственно, была его троюродной сестрой, а А.М. Бакунин - троюродным братом ${ }^{24}$. Под теми, кто «связаны дружбою с теми самыми людьми, кои писали и к кому писали», в обращении «К издателю» подразумевались многочисленные родственники и знакомые участников кружка, которые хотя и не участвовали в обсуждениях их произведений, но которым были внятны аллюзии в них.

Перечислю некоторые, наиболее важные факты творческого взаимодействия Львова и Бакунина. Вскоре после публикаций в «Музе» Львов пишет двучастную «Эпистолу к А.М. Бакунину из Павловского», датированную 14 июня 1797 года; в ней тщете и лицемерию придворной жизни противопоставлен гармоничный сельский уклад; в 1799 г. А.М. Бакунин дарит Львову рукописный сборник, состоящий из шести посвященных ему стихотворений ${ }^{25}$, Два года спустя Львов создает послание «Три „Нет“ у Николы в Воробине после смертельной моей болезни послание начерно к А.М. Б[акунину] 1801 октября 1-го».

Влияние Н.А. Львова на Бакунина было многосторонним, отразившись в стихах, которые создавались, видимо, как при жизни Львова, так и после его смерти, многократно перебеливались и редактировались. Нередко, как и во втором стихотворении, напеча-

24 О многообразных родственных связях Н.А. Львова через князей Мышецких см.: Дзюбанов С.Д. Родственное окружение Львовых: князья Мышецкие // Николай Львов: прошлое и современность. СПб., 2005. С. 22-23.

${ }^{25}$ Сборник воспроизведен в его целостности в кн.: Русская литература век XVIII. Лирика / Сост., подгот. текстов и коммент. Н.Д. Кочетковой, Е.Д. Кукушкиной, К.Ю. Лаппо-Данилевского и др. М., 1990. С. 532-536. 
танном в «Музе», Бакунин включал в них львовские строки. Еще Б.И. Коплан опубликовал три стихотворных «подражания» Бакунина Львову, написанных, видимо, в конце 1790-х годов: «Сон. Подраж[ание] Ник. Алек. Львову», «Разлука. Подражание мыслям стихов Ник. Алек. Львову», «Ночь. Подраж[ание] Ник. Алек. Львову» ${ }^{26}$. Вскоре после смерти друга, по-видимому, в 1804 г. Бакунин сводит воедино текст своих «Писем к Н.А. Л[ьвову]», цикла из семи писем, касающихся широкого спектра волнующих автора проблем (об этом можно судить хотя бы по названиям первых четырех из них: «О садах», «О климате», «О том же», «О народном характере»; последующие озаглавлены не были) ${ }^{27}$. В конце 1810 -х годов А.М. Бакунин собирает в тетради (бумага с водяными знаками 1818 г.) стихи, написанные, как представляется, в 1800-е годы, варьирующие темы стихов Львова и содержащие парафразы и цитаты из них ${ }^{28}$.

А.М. Бакунин был человеком скромным, к литературной известности не стремившимся, поэтому не удивительно, что Львов, ценивший талант своего более молодого друга, взял на себя инициативу публикации двух его стихотворений в «Музе» в 1796 году. Подобный случай не был единственным - в 1815 г. в «Чтении в Беседе любителей русского слова», на этот раз уже благодаря Капнисту и Державину, без указания имени автора была напечатана бакунинская «Жатва» ${ }^{29}$.

Но вернемся к свидетельству Мартынова о пяти литераторах, печатавшихся в «Музе». На данный момент не выявленными остаются лишь публикации Ф.П. Львова в этом журнале. Просмотр сборника его сочинений «Часы свободы в молодости», вышедшего в 1831 году $^{30}$, и его недавнего комментированного переизда-

${ }^{26}$ Коплан Б.И. Из литературных исканий конца XVIII - начала XIX в. (А.М. Бакунин и В.В. Капнист). Тверь, 1928. С. 18-19 (отд. оттиск из кн.: Материалы Общества по изучению Тверского края, 1928. Вып. 6). Подлинники этих трех стихотворных подражаний Н.А. Львову хранятся: ИРЛИ. Ф. 16 (Бакунины). Оп. 2. Ед. хр. 8. Л. 1 об.-2 об. В сборник стихов А.М. Бакунина 2001 года, подготовленный М.В. Строгановым, они почему-то не вошли.

${ }^{27}$ Письма А.М. Бакунина к Н.А. Львову / Публ. Л.Г. Агамалян // Ежегодник Рукописного отдела Пушкинского Дома на 1997 год. СПб., 2002. C. $43-95$.

${ }^{28}$ Стихи А.М. Бакунина, написанные в подражание Н.А. Львову / Публ. К.Ю. Лаппо-Данилевского // Ежегодник Рукописного отдела Пушкинского Дома на 1997 год. СПб., 2002. С. 33-42.

${ }_{29}$ [Бакунин А.М.] Жатва // Чтение в Беседе любителей русского слова. 1815. Чт. 18. С. 45-48. См. подробнее: Лаппо-Данилевский К.Ю. О первой публикации «Жатвы» А.М. Бакунина // Гений вкуса: Н.А. Львов. Материалы и исследования. Тверь, 2001. Сб. 2. С. 219-221.

30 Львов Ф.П. Часы свободы в молодости. СПб., 1831. Ч. 1-2. 
ния ${ }^{31}$, а также ряда рукописных материалов не дал положительного результата. Рискну выразить предположение, что Ф.П. Львову принадлежит анонимный «Мадригал. На розу найденную в партере $\mathrm{M}^{* * *}$ в ноябре месяце (подражание французскому)» ${ }^{32}$; к этому стихотворению сделана отсылка в тексте, несомненно принадлежащем Н.А. Львову. Имеется в виду авторское примечание к следующим строкам отрывка «К Доралисе», предуведомляющее львовские «Стихи на розу, сорванную зимою 1796 года и посланную в рисунке к Доралисе»: «Там весна, где ты живешь, прекрасная Доралиса! А здесь еще морозы. Несмотря на стужу, любовь не перестает однако делать обычные чудеса свои. Кто-то из ее счастливых подданных сорвал розу в саду Пафосском* в ноябре месяце, а мне сама Любовь поднесла розу уже в феврале месяце» ${ }^{33}$. Расшифровать содержащиеся в данном пассаже аллюзии на какие-то известные обоим авторам «Музы» события пока не представляется возможным, но их камерный характер не вызывает сомнений. Близкие дружеские отношения кузенов наводят на мысль о том, что Н.А. Львов мог здесь отсылать к стихотворению, написанному именно Ф.П. Львовым. Но все это только гипотеза. Нельзя исключить и того, что Ф.П. Львов ничего не печатал в «Музе», но исполнял несколько раз чьи-то поручения (к примеру, Державина или же Дмитриева) и доставил Мартынову какие-то литературные сочинения (анонимные или подписанные псевдонимами), а потому и был воспринят тем как их автор.

Что же касается участия Н.А. Львова в «Музе» - засвидетельствованное самим издателем журнала, но при этом принципиально анонимное, оно лишь с течением времени предстало в своем полном объеме (осмелюсь выразиться именно так, хотя, конечно, не могу исключить новых уточнений и дополнений). Именно Н.А. Львов стал тем, кто привнес на страницы «Музы» атмосферу домашности,

31 Львов Ф.П. Часы свободы в молодости / Изд. подгот. Е.Ю. Жаровой и М.В. Строгановым. Тверь, 2006. Нельзя не пожалеть, что составителям этого издания оказался неизвестен наиболее полный рукописный сборник литературных сочинений Ф.П. Львова, содержащий ряд неучтенных стихотворений («Сестре Паше при посылке „Скимнина“», «Шутка Никольского пива...» и др.), а также данные, важные и для текстологов и для комментаторов: РО ИРЛИ. Архив Я.К. Грота. 14384). На л. 139-174 об. здесь находятся произведения, исполнявшиеся на семейных праздниках с 1811 по 1817 год.

32 [Аноним]. Мадригал. На розу, найденную в партере М*** в ноябре месяце (подражание французскому) («Я роз искал везде...») // Муза. 1796. Ч. ІІ. Апр. С. 75-76.

${ }^{33}$ Муза. 1796. Ч. ІІ. Май. С. 131-132. От звездочки после слова «Пафосский» внизу страницы сделано следующее примечание: «Смотри в апреле месяце сего журнала мадригал на с. 75». 
дружеского эзотеризма, внятного лишь участникам львовско-державинского кружка и их родственного окружения ${ }^{34}$. Это, с одной стороны, происходило благодаря паратекстам (отрывок «К Доралисе», анонимное предисловие к стихам Слепецкого), с другой благодаря помещению на страницах журнала текстов дружеского характера, изначально для печати не предназначавшихся (обширный стихотворный пассаж из несохранившегося львовского письма к Бакунину, воспринимающийся как автономное дружеское послание) или же опубликованных ранее крайне малым тиражом для небольшого числа лиц (поэма «Зима»). Мистификация с поэтом Слепецким была явлением того же порядка — на страницах «Музы» по воле Н.А. Львова появились стихи автора, их к печати не предполагавшего и об этом сюрпризе, видимо, до последнего момента не догадывавшегося. И хотя избранный псевдоним надежно хранил от широкой аудитории имя А.М. Бакунина, но аллюзия на его слабое зрение позволяла дружескому и родственному окружению без труда и с точностью определить имя автора опубликованных стихов.

34 Думается, бо́льшая биографическая близость к Мартынову и немалая возрастная разница позволили Н.А. Львову осуществлять кружковую экспансию в «Музе» в куда бо́льшей степени, чем в изданиях Карамзина, в которых он в 1790-е годы также печатался. В карамзинских изданиях Львову без сомнения принадлежат лишь четыре произведения: в «Московском журнале» это «Письмо к П.Л. В[ельяминову] из Арпачева от 17 августа 1791» (1791. Ч. IV. Окт. С. 91-101; без подп.); в «Аонидах» - стихотворения «Музыка, или Семитония: Ода» (Аониды, или Собрание разных новых стихотворений. М., 1796. Кн. 1. С. 32-35; подп.: «Н. Л.»), «К Дорализе» (Там же. С. 183-184; подп.: «Н. Л.»), «Отпускная двум чижикам при отъезде в деревню к М[арии] А[лексеевне]» (Там же. С. 262-263; подп.: «Н. Л.»). А.Н. Неустроев в «Указателе к русским повременным изданиям и сборникам за 1703-1802 гг.» (1898) неверно атрибутирует Н.А. Львову три стихотворения: «К лире» в «Московском журнале» (1792. Ч. VI. С. 227-234; без подп.; автор Ф.П. Львов), «Прибавление к последней строфе» (Аониды. М., 1796. Кн. 1. С. 260-261; без подп.; автор Н.М. Карамзин) и «Облачок» (Аониды. М., 1797. Кн. 2. С. 232-233; подп.: NN; автор Ф.П. Львов). В связи с последним стихотворением укажу, что именно так подписаны почти все стихотворения Ф.П. Львова в «Московском журнале» Карамзина: [Львов Ф.П.] 1) Стансы («Где ты, мой друг? - Куда ты скрылось...») // Московский журнал. 1791. Ч. III. Июль. С. 4-6; подп.: NN (сообщены из Петербурга); 2) К Талажне («Восторгом сердце упоенно...») // Там же. 1792. Ч. IV. Июнь. С. 124-127; подп.: сочинено в Арпачеве $\mathrm{NN}$; 3) K пеночке («Пеночка моя драгая...») // Там же. 1792. Ч. VII. Кн. 3. Июнь. С. 113-118; подп.: NN (из Петербурга); 4) Цветок («Цветок любимый, ароматный!..») // Там же. 1792. Ч. VIII. Окт. и ноябрь. С. 111-114; подп.: NN (из Петербурга); 5) Доброму человеку («Блажен, кто средь честей блестящих...») // Там же. 1792. Ч. VIII. Дек. С. 202204; подп.: NN (из Петербурга). 


\section{Литература}

Артамонова 3. Неизданные стихи Н.А. Львова // Литературное наследство. 1933. № 9/10. С. 264-284.

Бакунин А.М. Собрание стихотворений / Изд. подгот. М.В. Строганов. Тверь: Золотая буква, 2001. 206 с.

Болотов А.T. Памятник протекших времен, или Краткие исторические записки о бывших происшествиях и носившихся в народе слухах. М., 1875. Ч. $1-2$.

Гаврилов А.К. Евгений Булгарис // Словарь русских писателей XVIII века. Л., 1988. Вып. 1: А-И. С. 132-136.

Залдкин А.Н. Иван Иванович Мартынов (1771-1833), деятель просвещения в начале XIX века. Тифлис, 1902. (Отт. из Циркуляра по Управлению Кавказским учебным округом. 1902. № 12. Прил. № 18).

Дзюбанов С.Д. «Верует в Резон, как во Единого Бога» (подлинная история тайной женитьбы Н.А. Львова) // Г.Р. Державин и его время. СПб., 2008. Вып. 4. С. 5-56.

Дзюбанов С.Д. Родственное окружение Львовых: князья Мышецкие // Николай Львов: прошлое и современность. СПб., 2005. С. 22-23.

Коплан Б.И. Из литературных исканий конца XVIII - начала XIX в. (А.М. Бакунин и В. В. Капнист). Тверь, 1928 (отд. оттиск из кн.: Материалы Общества по изучению Тверского края, 1928. Вып. 6).

Лаппо-Данилевский К.Ю. О первой публикации «Жатвы» А.М. Бакунина // Гений вкуса: Н.А. Львов. Материалы и исследования. Тверь, 2001. Сб. 2. С. 219-221.

Львов Ф.П. Часы свободы в молодости: Собр. соч. / Изд. подг. Е.Ю. Жарова и М.В. Строганов. Тверь: Марина, 2006. 384 с.

Мартынов И.И. Записки // Памятники новой русской истории. Сборник исторических статей и материалов, изд. В. Кашпиревым. Т. 2. СПб., 1872. С. 68-182 (2-ая паг.).

Русская литература - век XVIII. Лирика / Сост., подгот. текстов и коммент. Н.Д. Кочетковой, Е.Д. Кукушкиной, К.Ю. Лаппо-Данилевского и др. Вступ. ст. Н.Д. Кочетковой. М.: Художественная литература, 1990. 736 с.

Сводный каталог русской книги гражданской печати XVIII века: 1725 1800. M., 1966. T. IV: периодические и продолжающиеся издания.

Стихотворение Анакреона Тийского. Перевел **** **** [Н.А. Львов]. СПб., 1794. $44+289$ с.

Сысоев В.И. Бакунины. Тверь: Созвездие, 2002. 464 с.

\section{References}

Artamonova Z. "Neizdannye stikhi N.A. L'vova". Literaturnoe nasledstvo. 1933. № 9/10, pp. 264-284.

Bakunin A.M. Sobranie stikhotvorenii, ed. M.V. Stroganov. Tver', 2001. 206 p.

Bolotov A.T. Pamiatnik protekshikh vremen, ili Kratkie istoricheskie zapiski o byvshikh proisshestviiakh i nosivshikhsia v narode slukhakh. Moscow, 1875. Ch. 1-2.

Gavrilov A.K. "Evgenii Bulgaris”. Slovar' russkikh pisatelei XVIII veka. Leningrad, 1988. Issue 1: A-I, pp. 132-136. 
Zaldkin A.N. Ivan Ivanovich Martynov (1771-1833), deiatel' prosveshcheniia $v$ nachale XIX veka. Tiflis, 1902.

Dziubanov S.D. “'Veruet v Rezon, kak vo Edinogo Boga' (podlinnaia istoriia tainoi zhenit'by N.A. L'vova)". G.R. Derzhavin $i$ ego vremia. Saint-Petersburg, 2008. Issue. 4, pp. 5-56.

Dziubanov S.D. "Rodstvennoe okruzhenie L'vovykh: kniaz'ia Myshetskie". Nikolai L'vov: proshloe i sovremennost'. Saint-Petersburg, 2005, pp. 22-23.

Koplan B.I. Iz literaturnykh iskanii kontsa XVIII - nachala XIX v. (A.M. Bakunin $i$ V.V. Kapnist). Tver', 1928, from: Materialy Obshchestva po izucheniiu Tverskogo kraia, 1928. Issue. 6.

Lappo-Danilevskii K.Iu. "O pervoi publikatsii 'Zhatvy' A.M. Bakunina”. Genii vkusa: N.A. L'vov. Materialy i issledovaniia. Tver', 2001. Issue 2, pp. 219221.

L'vov F.P. Chasy svobody v molodosti, ed. by E.Iu. Zharova, M.V. Stroganov. Tver', 2006. 384 p.

Martynov I.I. "Zapiski". Pamiatniki novoi russkoi istorii. Sbornik istoricheskikh statei $i$ materialov, ed. by V. Kashpirevym. Vol. 2. St.-Petersburg, 1872, pp. 68-182 (2nd paging).

Russkaia literatura - vek XVIII. Lirika, ed., comm. by N.D. Kochetkova, E.D. Kukushkina, K.Iu. Lappo-Danilevsky et al. Preface by N.D. Kochetkova. Moscow, 1990. 736 p.

Svodnyi katalog russkoi knigi grazhdanskoi pechati XVIII veka: 1725-1800. Moscow, 1966. Vol. IV: Periodicheskie i prodolzhaiushchiesia izdaniia.

Stikhotvorenie Anakreona Tiiskogo, transl. ******** [N. A. L'vov]. St.-Petersburg, 1794. $44+289 \mathrm{p}$.

Sysoev V.I. Bakuniny. Tver', 2002. 464 p.

\title{
Alexander Slepetskoy, the Poet. A Pseudograph in the journal Muza (1796)
}

\author{
K.Yu. Lappo-Danilevsky
}

Abstract: The article is devoted to the pen-name that for over 220 years concealed the true name of the poet Alexander Mikhailovich Bakunin (17681854). Nikolay Alexanrovich L'vov (1753-1803) wrote a small preface to his poems, therefore it is reasonable to consider both of them in the context of other publications by the members of L'vov's and Derzhavin's circle in the journal Muza. The article offers several hypotheses and aims at specifying cryptonyms used in Muza as well as in N.M. Karamzin's editions of the 1790-ies.

Keywords: attribution, pen-names, N.A. L'vov, A.M. Bakunin, L'vov's and Derzhavin's circle, the journal Muza.

Information about the author: Konstantin Yu. Lapo-Danilevsky, Doctor Habil. of Philology, Institute of Russian Literature (Pushkin House) of the Russian Acadmy of Sciences, Saint-Petersburg. E-mail: litfact@gmail.com 